\title{
Editorial: The European Union's External Energy Policy
}

\section{Anke Schmidt-Felzmann}

THIS IS A PARTICULARLY APPROPRIATE MOMENT FOR THE PUBLICATION OF A SPECIAL ISSUE on the European Union's External Energy Policy. With the rising price of fuel on the world market, over the past months energy supply security has become an issue of vital importance to many governments (if it had not been that already). The implications of the present 'crisis in oil prices', both for the individual citizen and the economy as a whole, and especially the fisheries sector, were extensively debated at the recent European Council (1920 June 2008) in Brussels. The crisis came as a shock to many, but analysts had already predicted that the inevitable emergence of a shortage of supplies on the global market would have severe economic consequences for many.

In recent years, the protection of 'critical energy infrastructure' has been included on the agenda of the North Atlantic Treaty Organisation (NATO), and the security of energy supply has become one of the most prominent and pressing issues on the EU's agenda as global demand begins to outstrip supplies of fossil fuels. The Union's import dependence on natural gas and crude oil has been gradually increasing as domestic production of solid fuels, gas and oil is declining rapidly even in the traditional energy exporting countries. Despite technological advancements in the sector of renewables (bio-fuels, wind and hydro-energy), the growing demand cannot be fully met by these alternative energy sources. For many governments this, and the need to reduce carbon emissions to combat climate change, has meant revisiting their decision against the use of nuclear power to generate electricity for domestic and export markets. While atomic energy continues to be highly controversial, and member states remain divided over whether or not to include or retain atomic energy to meet rising demands, support for the 'clean' nuclear option is certainly on the rise. The European Commission has in any case been careful to honour the principle of subsidiarity in its proposals for a common energy policy, leaving the choice of energy mix for the national governments to decide.

However the liberalisation of the electricity and gas market is another matter entirely. The European Commission has been pursuing full liberalisation of the electricity and gas markets for a number of years now. The establishment of a liberalised open single market would go hand in hand with the abolition of protectionist measures at the national level. These moves have been met with considerable resistance by some member states intent on protecting their 'national energy champions'. Cleavages among member states are indeed presenting formidable obstacles to the forging of a common EU internal energy policy. This is especially true regarding the questions of whether (1) the energy sector is of such strategic importance that it must be state-controlled rather than directed from the supranational level and by market forces; or (2) it is the full liberalisation of the market that will better be able to ensure national supply security. In parallel with growing concern over difficulties in ensuring secure provision of fuels, energy security has also become an integral part of the Union's bilateral and multilateral cooperation agreements with third countries. The fundamental questions of whether or not energy should be controlled by market forces or overseen by national governments act also as obstacles to the adoption of a common external energy strategy that would win the unreserved support of all 27 states. 
The EU has thus encountered significant difficulties in the development and execution of its nascent external energy strategy not only within the EU itself, but proposed policies have also been resisted by external parties. At their recent summit meeting in Khanti Mansiisk (2627 June 2008), the EU and Russia reaffirmed their commitment to the dialogue on energy and especially the predictability and safety of demand and supply. The recent launch of negotiations on a New Agreement that is to replace the existing Partnership and Cooperation Agreement of 1994 constitutes a first step in what is predicted to be a long and arduous political process. Energy is one of the key issues that the EU and Russia are set to agree basic principles of engagement on. Among the principles which the EU would like to see enshrined in the New Agreement are the stipulations of the Energy Charter Treaty and its Transit Protocol which were signed, but not ratified by Russia.

Over the past year a number of member countries that are heavily reliant on energy imports have come under sever criticism for concluding new, and renewing existing, long-term bilateral energy deals with the Russian Federation in an attempt to safeguard their national energy supplies despite agreement at the EU level on the need for a 'common', unified approach towards this and other supply states. Some member states and the European Commission have argued that these individual deals undermine the declared aim for the whole of the EU to diversify its energy provision, in terms of supply routes and supply sources and to achieve greater security by reducing, rather than increasing, EU dependence on a single supplier. Those having already concluded such agreements are adamant that they are simply exercising their sovereign right to protect their national supply security, and that one may not speak of a 'breach' of the common energy policy, when its shape remains in flux and its principles highly contested among the member states.

In the wake of the disputes over a steep increase in gas prices between Russia and Ukraine (as well as Belarus and Georgia) which we have witnessed over the past couple of years, concerns about reliance on Russia as the main, or even only supplier of oil and gas have given rise to demands for enshrining 'EU solidarity' as one of the key principles for the Union's member countries. Dedicated lobbying efforts by some of the Central and Eastern European member states resulted in the inclusion of an 'energy solidarity clause' in the Treaty on the Functioning of the European Union (2007), better known as the 'Lisbon Treaty' (see Article 176A, consolidated version). However it remains doubtful whether this stipulation will be honoured, and in which fashion this may be the case. After the Irish no-vote in the referendum of 12 June 2008 on the ratification of the Lisbon Treaty, it is in any case unlikely that the 'solidarity clause' will become part of the acquis communautaire in the foreseeable future.

In parallel with rising concerns among the political leadership about how to ensure energy supply security in the EU, and after the comparatively low levels of interest among researchers during the 1990s - a period of cheaper fuel prices - we are now seeing a flurry of publications on EU energy policy and in particular its emerging external dimension. The contributions in this issue each address a key aspect of the dilemmas EU policy-makers are facing in the development of a common external energy policy.

The first contribution by Michal Natorski and Anna Herranz Surrallés critically examines the 'securitization' of energy policy in the EU. Their article carefully traces the development of the prevalent discourses on energy by the European Parliament, the European Commission (and individual Commissioners), the Council and some of the member states during 20052007. Their focus is on the question what different actors within the EU actually mean by energy security, whether there were windows of opportunity for collective action, and what are the implications of this for the development of a common energy policy. Their findings highlight the effects of the divergent understandings of energy security within the EU on the shape and effectiveness of the common external policy. In particular, the article illustrates the persistent concern among member states about a potential transfer of sovereignty to the EU level in a sector of such strategic importance which they strongly resist. As Natorski and Herranz Surrallés demonstrate, the reservations by some member states against pooling 
sovereignty in the energy sector, act as a real obstacle to the implementation of the measures proposed by the European Commission with a view to enhancing the supply security of the EU as a whole.

The second article, by Francis McGowan, picks up the debate about national sovereignty and places it in the context of the dilemmas states are being faced with in the 'new' contemporary global energy policy environment. His contribution focuses on the inherent tension between the European Commission's push for a full liberalization of the EU's internal energy market in the face of renewed 'economic nationalism' by some member states, as well as some third party countries that the EU's policies are aimed towards. The article illustrates why key aspects of the market-led approach to energy security are contested internally, and externally by the major energy supplying countries, Russia and Algeria. McGowan sketches the main issues associated with debates about whether and how to allow third country energy suppliers market access in the upstream and downstream sectors of the EU departing from the Commission's proposed move towards 'ownership unbundling' of assets, most notably the stipulations known as the 'Gazprom-clause'. He concludes that the EU's strategy of relying on energy market liberalization to enhance security of supplies may not be as effective as it is claimed because of the inherent contradiction between the economic nationalism of individual states (within and outside of the EU) and the promotion of a comprehensive market-led approach to energy diplomacy.

In the third article Pamela M. Barnes addresses the energy interdependencies in the European neighbourhood and their implications for the EU's external energy policy. In her contribution she focuses on the role of nuclear power in the supply mix and in particular the difficulties faced by the EU in reforming the European Atomic Energy Community after more than 50 years of its existence. She convincingly illustrates the continuing relevance and importance of the Euratom Treaty (1957) with reference to the new member states that joined the EU in 2004 and 2007. As she explains, the EU's regulatory framework for atomic energy served to effect successful upgrading of the safety standards in Bulgaria and Lithuania. The EU's enlargement policy in this sector serves also as a model for its engagement with the new eastern neighbours. With regard to the Eastern neighbourhood, Barnes discusses the cases of Ukraine and Armenia who are, besides Russia, the only third countries in this region that use nuclear energy. These cases serve to highlight the decisive role of Russia in the wider European region, and the competition the EU is facing by the country in its policies towards the eastern neighbours. She concludes that the difficulties faced by the EU in its external energy policy can only be resolved by firstly developing a coherent EU policy internally and secondly, by establishing cooperative relations with Russia in the shared neighbourhood for the benefit of all parties involved in the 'triangular relationship'.

The fourth article, by Valentina Feklyunina, picks up the theme of competition over energy between the EU and Russia in the shared neighbourhood. Her contribution focuses specifically on the geopolitics of energy in Central Asia and the conflict that has arisen between the EU's and Russia's respective pipeline projects in the Caspian region. Both their diversification plans are aimed at enhancing 'energy security', including that of supply from different sources on the part of the EU, and that of securing long-term contracts with a broad consumer base as well as additional supplies to top up its own resources on the part of Russia. She analyses this issue from the vantage point of the Russian elites who are, as she contends, intent on rebuilding Russia's status as a great power. In the discussion of divergences and contradictions between the EU's declared intentions and mutual distrust, her analysis of the dominant discourses of the Russian political elites regarding the EU's diversification plans highlights the important role of Russia's 'self-image' in the Kremlin's foreign energy policy towards 'the West'.

In his contribution, Lutz Güllner raises important issues which he himself, from the practitioner's perspective, would wish to see addressed in the research that is currently being conducted into EU external energy policy, especially regarding Russia's role in the European energy security debate. Firstly he contends that rather than accept that Russia 'has power' 
over a 'vulnerable EU', researchers should discuss the entanglements between Russia and the EU concerning energy security in a more nuanced way and clarify what exactly are the issues at stake. Before analysing the EU's policy options, researchers should carefully dissect and scrutinize the complex energy relations, and notably make a distinction between whether there is a 'real threat' vs. a 'potential risk' of energy insecurity when speaking about the EU's dependence on Russia. Further, 'state-controlled companies' and 'state-actors' should be differentiated in the analysis, and a clear distinction be drawn between the different energy products; as markets for coal and oil are global, whereas the gas market remains essentially regional. Finally he argues that the question of supply insecurity should be examined in terms of three distinct dimensions of risk: material, economic and political. This would add scientific rigour and depth to the current debates on energy security. Research which takes these considerations on board could make a desirable and valuable contribution to the ongoing policy debates among the political elites.

The final contribution consists of a review of three recent contributions to the literature on energy security, by Jack Sharples and James D.J. Brown. These are two monographs, one on European energy security from a legal perspective (Haghighi 2007), the other a case study of Ukraine's energy relations with Russia (Balmaceda 2008) and an edited volume on EU energy policy from a regional perspective (Aalto 2008), with a focus on Northern Europe and the EURussian energy dialogue. Both reviewers provide a commendable concise overview and insightful discussion of these books, highlighting their strengths and weaknesses as well as the kind of readership these books are suited to.

The workshop 'Security of Energy Supply in the New Europe - A Challenge for the European Neighbourhood Policy?' (19-20 September 2007), which brought together the authors and reviewers featured in this special issue, was hosted by the Department of Politics at the University of Glasgow and was jointly organised by Valentina Feklyunina and myself. Earlier versions of the four articles were presented and benefited from discussions at this workshop and I would like to thank all participants for their valuable contributions. I would also like to thank Alasdair Young for his advice and guidance during the preparation of the workshop. Further I would like to acknowledge the generous financial support by UACES, the Glasgowbased Centre for Russian, Central and East European Studies (CRCEES), the Scottish Jean Monnet Centre as well as the Faculty of Law, Business and Social Sciences and the Department of Politics of the University of Glasgow.

I would also like to thank the referees for their thorough reviews and helpful comments on the articles included in this issue. And last but not least, I am very grateful to Eamonn Butler for his absolutely outstanding commitment to the editing of this issue and his support, well above and beyond the call of duty, during the final stages of the publication process. 